\title{
PENGUNGKAPAN MANAJEMEN LABA: PERENCANAAN PAJAK DAN ASET PAJAK TANGGUHAN PADA PERUSAHAAN YANG TERDAFTAR DI BEI
}

\author{
Dian Pratiwi ${ }^{1}$, Diah Ayu Susanti ${ }^{2}$ \\ Program Studi Akuntansi, Fakultas Ekonomi dan Bisnis, Universitas Muria Kudus \\ 1dianpratiwi.dp5@gmail.com \\ 2diah.ayu@umk.ac.id
}

\begin{abstract}
ABSTRAK
Penelitian ini bertujuan menguji pengaruh perencanaan pajak dan aset pajak tangguhan terhadap pengungkapan manajemen laba. populasi dalam penelitian ini mencakup seluruh perusahan yang terdaftar di Bursa Efek Indonesia pada tahun 20132016. Pengambilan sampel menggunakan teknik purposive sampling, yaitu sampel dipilih dengan menggunakan kriteria tertentu sesuai dengan tujuan dan masalah penelitian yang dikembangkan sehingga sampel dalam penelitian ini adalah 300 perusahaan. Teknik yang digunakan yaitu statistik deskriptif dan metode regresi logistik. Berdasarkan hasil analisis ditemukan bahwa perencanaan pajak berpengaruh positif terhadap manajemen laba dan aset pajak tangguhan tidak berpengaruh terhadap manajemen laba.
\end{abstract}

Kata Kunci : perencanaan pajak, aset pajak tangguhan, manajemen laba.

\section{ABSTRACT}

This study aims to examine the effect of tax planning, and deferred tax assets to earnings management. The population in this study covers all companies listed on the Indonesia Stock Exchange. The research period used in this research is 2013-2016. Sampling using purposive sampling technique, the sample selected by using certain criteria in accordance with the objectives and research problems developed so that the sample in this study amounted to 300 companies. The technique used is descriptive statistics and logistic regression method. Based on the results of the analysis found that tax planning positive effect on earnings management, and deferred tax assets have no significant effect on earnings management.

Keywords: tax planning, deferred tax assets, earnings management

\section{PENDAHULUAN}

Penilaian kinerja suatu perusahaan dapat dilihat dari pencapaian laba yang diperoleh perusahaan tersebut. Kualitas laba menjadi pusat perhatian bagi para investor, kreditor, pembuat kebijakan akuntansi, dan pemerintah dalam hal ini Direktorat Jenderal Pajak (Endriati dkk, 2017). Informasi laba yang merupakan komponen dari laporan keuangan haruslah menggambarkan keadaan perusahaan yang sebenarnya, namun pada kenyataannya pihak manajemen seringkali memanipulasi laporan keuangan untuk kepentingan-kepentingan tertentu. Menurut Tundjung (2015) tindakan manajemen memanipulasi laporan keuangan mengidentifikasikan adanya praktik manajemen laba pada perusahaan.

Manajemen laba merupakan pengungkapan manajemen sebagai alat intervensi langsung manajemen dalam proses pelaporan keuangan melalui pengolahan pendapatan 
atau keuntungan dengan maksud untuk mendapatkan keuntungan atau manfaat tertentu bagi manajer maupun perusahaan yang dilandasi oleh faktor ekonomi (Negara dan Suputra, 2017). Sekilas tampak bahwa manajemen laba berhubungan erat dengan tingkat perolehan laba (earnings) atau kinerja perusahaan. Hal tersebut karena tingkat laba yang diperoleh dikaitkan dengan kinerja manajemen (Hery, 2012:53).

Manajemen laba bisa dikategorikan sebagai suatu penipuan yang bisa merugikan pihak-pihak yang berkepentingan seperti user, investor dan pemerintah karena informasi yang diberikan tidak mencerminkan kondisi ekonomi perusahaan yang sebenarnya (Pindiharti, 2011). Sulistiawan dkk (2011:31) menyebutkan ada enam motivasi individu atau badan usaha melakukan manajemen laba, yaitu (1) Motivasi bonus, (2) Motivasi utang, (3) Motivasi pajak, (4) Motivasi penjualan saham, (5) Motivasi pergantian direksi, dan (6) Motivasi politis. Dimana perusahaan dapat melakukan praktik manajemen laba dengan 4 pola yaitu (1) Taking a bath, dengan cara mengatur laba perusahaan menjadi sangat tinggi atau rendah dibanding tahun sebelumnya. (2) Income minimization, dengan cara menjadikan laba periode tahun berjalan lebih rendah dari sebenarnya. (3) Income maximization, dengan cara menjadikan laba tahun berjalan lebih tinggi dari sebenarnya dan (4) Income Smoothing, dengan cara mengurangi fluktuasi laba sehingga laba yang dilaporkan relatif stabil (Scoot, 2000).

Tabel 1.1

Kasus Manajemen Laba yang Terjadi di Indonesia

\begin{tabular}{|c|c|l|l|}
\hline No. & Tahun & \multicolumn{1}{|c|}{ Nama Emiten } & \multicolumn{1}{|c|}{ Kasus } \\
\hline 1. & 2007 & PT Agis Tbk & $\begin{array}{l}\text { Melaporkan mark up laba, yaitu laba yang dilaporkan } \\
\text { disajikan lebih tinggi dari yang sebenarnya yang } \\
\text { artinya PT Agis Tbk melakukan income maximization } \\
\text { (Bapepam.go.id) }\end{array}$ \\
\hline 2. & 2009 & PT Waskita Karya Tbk & $\begin{array}{l}\text { Mencatat kelebihan penyajian dalam laporan keuangan, } \\
\text { perusahaan mencatat nilai dalam kontrak lebih tinggi } \\
\text { dari sebenarnya yang artinya PT Waskita Karya Tbk } \\
\text { melakukan income maximization (finance.detik.com). }\end{array}$ \\
\hline 3. & 2010 & PT Elnusa & $\begin{array}{l}\text { Penyalahgunaan cadangan dana menyebabkan seolah } \\
\text { perusahaan seolah memiliki keuntungan tinggi namun } \\
\text { sebenarnya perusahaan berada dalam kondisi kritis } \\
\text { artinya PT Elnusa Tbk melakukan income } \\
\text { maximization (www.detik.com). }\end{array}$ \\
\hline 4. & 2010 & PT Bumi Resources Tbk & $\begin{array}{l}\text { Melaporkan data penjualan yang lebih rendah dari } \\
\text { sebenarnya sehingga mengakibatkan kerugian negara } \\
\text { dari kekurangan bayar pajak artinya PT Bumi } \\
\text { Resources Tbk melakukan income minimization } \\
\text { (bisnis.tempo.co). }\end{array}$ \\
\hline 5. & 2015 & PT Timah Tbk & \begin{tabular}{l} 
Membuat laporan keuangan fiktif guna menutupi \\
\hline
\end{tabular} \\
\hline
\end{tabular}




\begin{tabular}{|l|l|l|}
\hline & & $\begin{array}{l}\text { kondisi perusahaan yang menghawatirkan artinya PT } \\
\text { Timah Tbk melakukan income maximization } \\
\text { (ekonomi.okezone.com). }\end{array}$ \\
\hline
\end{tabular}

Sumber : Berbagai Berita.

Permasalahan yang mengakibatkan terjadinya manajemen laba adalah adanya keinginan dari manajemen untuk menampilkan kinerja perusahaan terlihat baik dengan melaporkan perolehan laba yang maksimal, karena penilaian kinerja sebuah perusahaan dapat tercermin dari pencapaian laba tersebut. Keinginan tersebut dipicu karena adanya beberapa motivasi yaitu motivasi bonus, motivasi utang, motivasi pajak, motivasi penjualan saham, motivasi pergantian direksi dan motivasi politis.

Manajemen laba dapat dipengaruhi oleh beberapa faktor antara lain perencanaan pajak dan aset pajak tangguhan. Kedua faktor tersebut mempunyai peran penting dalam mengakibatkan berkurang ataupun bertambahnya laba, sehingga rumusan masalah yang disampaikan dalam penelitian ini adalah pengaruh perencanaan pajak, beban pajak tangguhan dan aset pajak tangguhan terhadap manajemen laba, maka dari itu tujuan dalam penelitian ini adalah untuk menganalisis pengaruh perencanaan pajak dan aset pajak tangguhan terhadap manajemen laba pada seluruh perusahaan yang terdaftar di Bursa Efek Indonesia tahun 2013-2016.

Dampak dari teori akuntansi positif menimbulkan hubungan keagenan yang dijelaskan dalam teori keagenan (agency theory) yaitu hubungan antara (1) Manajemen (agent) dengan pemilik (principal). Agent yang termotivasi untuk meningkatkan laba perusahaan dengan harapan mendapatkan kompensasi berupa bonus, sedangkan principal termotivasi mengadakan kontrak untuk menyejahterakan dirinya melalui pembagian dividen atau kenaikan harga saham perusahaan. (2) Manajemen (agent) dengan kreditur (prinsipal). Agent termotivasi untuk dapat mempertahankan rasio hutang terhadap modal perusahaan sedangkan prinsipal berkepentingan mempertimbangkan pemberian hutang terhadap agent dengan menggunakan laporan keuangan sebagai dasar pertimbangan. (3) Manajemen (agent) dengan pemerintah (prinsipal). Agent berkeinginan untuk meminimalkan pembayaran pajak, sedangkan prinsipal berkeinginan untuk menarik pajak sesuai dengan peraturan yang berlaku.

\section{TINJAUAN PUSTAKA}

\section{Teori Akuntansi Positif}

Dalam teori akuntansi positif menyebutkan ada tiga hipotesis yang digunakan (Watt dan Zimmerman, 1989), yaitu: 
a. Hipotesis Rencana Bonus (The Bonus Plan Hypothesis)

b. Hipotesis perjanjian hutang (The Debt Covenant Hypothesis)

c. Hipotesis Biaya Politik (The Cost Hypothesis)

\section{Teori Keagenan}

Teori keagenan menyatakan bahwa antara manajemen dan pemilik mempunyai kepentingan yang berbeda (Jensen dan Meckling, 1976). Menurut Anis dan Ghozali (2003), terdapat tiga macam hubungan keagenan yang muncul sebagai dampak hipotesis teori akuntansi positif yang dikemukakan oleh Watt dan Zimmerman (1986), antara lain:

a. Hubungan Manajer dengan Pemilik

b. Hubungan Manajer dengan Kreditur

c. Hubungan Manajer dengan Pemerintah

\section{Kerangka Pemikiran}

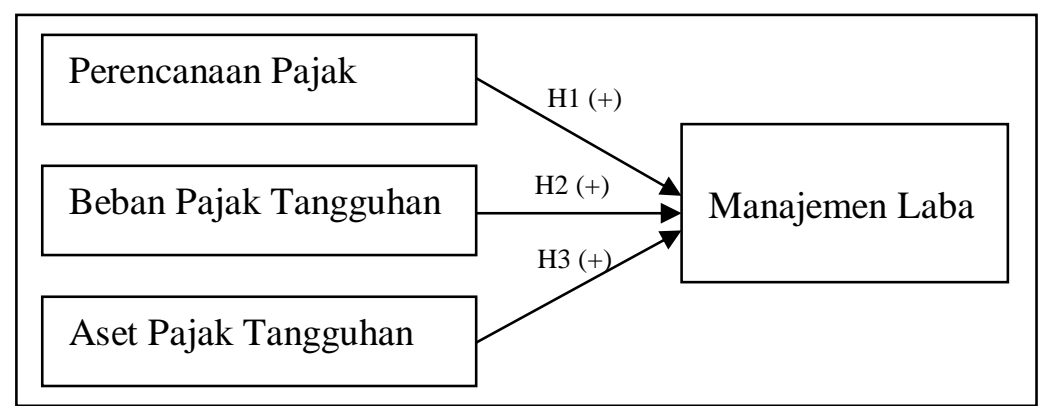

Sumber : Negara dan Suputra (2017). Dikembangkan untuk penelitian ini.

\section{Hipotesis}

\section{Pengaruh Perencanaan Pajak Terhadap Manajemen Laba}

Perusahaan akan melakukan perencanaan pajak seefektif mungkin, dengan tujuan untuk memperoleh keuntungan dari segi fiskal dan juga memperoleh keuntungan dalam memperoleh tambahan modal dari investor melalui penjualan saham. Status perusahaan yang sudah go public umumnya cenderung hight profile daripada perusahaan yang belum go public (Aditama, 2014). Sehingga untuk meningkatkan nilai saham perusahaan, maka manajemen termotivasi untuk memberikan informasi kinerja perusahaan sebaik mungkin. Oleh karena itu, pajak yang merupakan unsur pengurang laba yang tersedia untuk dibagi kepada investor atau diinvestasikan oleh perusahaan, akan diusahakan oleh manajemen untuk diminimalkan guna mengoptimalkan jumlah dari laba bersih perusahaan. 
Negara dan Suputra (2017) dan Santana dan Wirakusuma (2016) menyebutkan hasil bahwa perencanaan pajak memiliki pengaruh positif terhadap variabel manajemen laba.Berdasarkan uraian tersebut maka dapat dirumuskan hipotesis, yaitu:

\section{H1 : Perencanaan Pajak Berpengaruh Positif Terhadap Manajemen Laba.}

\section{Pengaruh Aset Pajak Tangguhan Terhadap Manajemen Laba}

Aset pajak tangguhan terjadi bila laba akuntansi lebih besar daripada laba fiskal akibat perbedaan temporer. Lebih besarnya laba fiskal mengakibatkan perusahaan menunda pajak terutang periode mendatang (Pindiharti, 2011). Adanya keterkaitan yang erat antara aset pajak tangguhan dengan ketentuan perpajakan menyebabkan perusahaan melakukan manajemen laba memanfaatkan aset pajak tangguhan, maksudnya bila manajer memanfaatkan aset pajak tangguhan pada laporan keuangan komersial untuk melakukan manajemen laba, maka hal ini dapat berimbas pada laporan keuangan fiskalnya karena aset pajak tangguhan dilaporkan pada laporan keuangan komersil dalam jangka waktu panjangnya harus match dengan laporan keuangan fiskalnya, sehingga manajer harus lebih memutar otaknya agar jumlah aset pajak tangguhan yang direkayasa tidak menyebabkan pembayaran pajak yang besar yang akan merugikan perusahaan (Widiastuti dan Chusniah, 2011).

Hakim dan Praptoyo (2015) dan Purba (2016) menyatakan bahwa aset pajak tangguhan memiliki pengaruh positif signifikan terhadap manajemen laba. Berdasarkan uraian tersebut maka dapat dirumuskan hipotesis sebagai berikut:

\section{H2 : Aset Pajak Tangguhan Berpengaruh Positif Terhadap Manajemen Laba. III. METODE PENELITIAN}

Penelitian ini dilakukan di Bursa Efek Indonesia (BEI) dengan mengakses situs resmi BEI yaitu www.idx.com. Penelitian ini dilakukan pada seluruh perusahaan yang terdaftar di Bursa Efek Indonesia. Objek penelitian ini adalah faktor-faktor yang mempengaruhi manajemen laba seperti perencanaan pajak dan aset pajak tangguhan.

Variabel dependen yang digunakan dalam penelitian ini adalah manajemen laba (Y), sedangkan variabel independen adalah perencanaan pajak (X1) dan aset pajak tangguhan (X2). Variabel dependen dalam penelitian ini adalah manajemen laba. Manajemen laba merupakan sebuah usaha yang dilakukan oleh manajemen untuk memanipulasi angkaangka akuntansi yang dilaporkan kepada pihak eksternal dengan tujuan untuk keuntungan bagi dirinya sendiri dengan cara mengubah atau mengabaikan standar akuntansi yang telah ditetapkan, sehingga menyajikan informasi yang tidak sebenarnya (Pindiharti, 2011) 
Dalam penelitian ini, menggunakan distribusi laba dalam mengukur manajemen laba. Berdasarkan penelitian yang dilakukan oleh Phillips dkk (2003), rumus untuk variabel manajemen laba di ukur dengan menggunakan pendekatan distribusi laba adalah sebagai berikut:

$$
\Delta \mathrm{E}=\frac{\text { Eit }- \text { EBit-1 }}{\text { MVEBit-1 }}
$$

Sumber: Philip dkk (2003)

Keterangan:

$\Delta \mathrm{E}$

$=$ Distribusi laba

Eit $\quad=$ Laba perusahaan i pada tahun $\mathrm{t}$.

EBit-1 = Laba perusahaan i pada tahun $\mathrm{t}-1$.

MVEBit-1 = Market Value Equity perusahaan i pada tahun t-1. MVE diukur dengan mengalikan jumlah saham yang beredar perusahaan i pada akhir tahun t-1 dengan harga saham perusahaan i pada akhir tahun $\mathrm{t}-1$.

Manajemen laba akan diberi kode 1 bila termasuk ke dalam kelompok small profit firms dan kode 0 bila termasuk ke dalam kelompok small loss firms. Menurut Yulianti (2004) perusahaan yang berada pada range 0 s/d 0,06 dikategorikan sebagai small profit firms, sedangkan perusahaan yang berada pada range $-0,09$ s/d 0 dikategorikan sebagai small loss firms.

Variabel independen atau variabel bebas adalah variabel yang memengaruhi variabel terikat, entah secara positif atau negatif. Yaitu, jika terdapat variabel bebas, variabel terikat juga hadir dan setiap unit kenaikannya dalam variabel bebas, terdapat pula kenaikan atau kenaikan dalam variabel terikat. Dengan kata lain variabel terikat ditentukan oleh variabel bebas (Sekaran, 2007 :117). Variabel independen dalam penelitian ini adalah perencanaan pajak dan aset pajak tangguhan.

Perencanaan pajak adalah suatu strategi yang dilakukan oleh perusahaan untuk meminimalkan beban pajak ditahun berjalan ataupun ditahun yang akan datang guna menekan beban pajak yang harus dibayarkan, tetapi masih dalam bingkai peraturan perpajakan (Santana dan Wirakusuma, 2016). Perencanaan pajak diukur dengan menggunakan tax retention rate (tingkat retensi pajak), yang menganalisis suatu ukuran dari efektivitas manajemen pajak pada laporan keuangan perusahaan tahun berjalan (Wild dkk, 2004). Ukuran efektifitas manajemen pajak yang dimaksud dalam penelitian ini yaitu 
ukuran efektifitas perencanaan pajak. Rumus tax retention rate (tingkat retensi pajak) adalah:

$$
\mathrm{TRR}=\frac{\text { Net Income it }}{\text { Pretax Income it }}
$$

Sumber : Wild dkk (2004)

Keterangan :

TRR

$=$ Tax Retention Rate perusahaan i pada tahun $\mathrm{t}$.

Net Income it $\quad=$ Laba bersih perusahaan i pada tahun $\mathrm{t}$.

Pretax Income it = Laba sebelum pajak perusahaan $\mathrm{i}$ tahun $\mathrm{t}$.

Aset pajak tangguhan adalah aset yang terjadi apabila perbedaan waktu (temporer) menyebabkan koreksi positif yang berakibat beban pajak menurut akuntansi komersial lebih kecil menurut Undang-Undang Pajak (Mettawidya, 2015). Dalam penelitian ini aset pajak tangguhan sebagai variabel independen dapat diukur dengan perubahan nilai aset pajak tangguhan pada akhir periode $\mathrm{t}$ dengan Bit-1 dibagi dengan nilai aset pajak tangguhan pada akhir periode t. Rumusnya adalah sebagai berikut:

$$
\text { DTA }=\frac{\text { Aset Pajak Tangguhan } \mathrm{t}}{\text { Aset Pajak Tangguhan it }}
$$

Sumber : Mettawidya (2015)

Keterangan:

DTA

= Deffered Tax Assets (Aset Pajak Tangguhan)

Aset Pajak Tangguhan $\mathrm{t}=$ Perubahan nilai aset pajak tangguhan it dengan Bit -1

Aset Pajak Tangguhan it $=$ Nilai aset pajak tangguhan akhir periode $\mathrm{t}$

Penelitian ini menggunakan statistik deskriptif dan metode regresi logistik. Statistik deskriptif digunakan untuk mendeskripsikan data yang bersifat kuantitatif menjadi data kualitatuf guna memberikan kemudahan dalam menginterpretasikannya. Regresi logistik digunkana untuk menguji apakah variabel independen mempunyai penyaruh dalam mendeteksi manajemen laba. model regresi logistik yang digunakan untuk menguji hipotesis adalah sebagai berikut:

$$
\operatorname{Ln} \frac{E M}{1-E M}=\alpha+\beta 1 T R R+\beta 2 D T E+\beta 3 D T A+e
$$


Keterangan:

$\begin{array}{ll}\text { Ln } & =\text { Variabel dummy } \\ \text { EM } & =\text { Earning Management (Manajemen Laba) Kode } 1 \text { jika perusahaan berada } \\ & \text { dalam range small profit firm dan kode } 0 \text { jika perusahaan berada dalam } \\ & \text { range small loss firm. } \\ \text { TRR } & =\text { Tax Retention Rate (tingkat retensi pajak) perusahaan i pada tahun } \mathrm{t} \\ \text { DTE } & =\text { Deferred Tax Expense (beban pajak tangguhan) perusahaan i pada tahun } \mathrm{t} \\ & \text { dibagi dengan Total Asset pada akhir tahun Bit-1. } \\ \text { DTA } & =\text { Deferred Tax Asset (aset pajak tangguhan) dari perusahaan nilai aset pajak } \\ & \text { tangguhan pada t dengan Bit-1 dibagi nilai aset pajak tangguhan periode t. } \\ & =\text { Error term }\end{array}$

\section{HASIL DAN PEMBAHASAN}

\section{Deskripsi Objek Penelitian}

Populasi dalam penelitian ini adalah seluruh perusahaan yang terdaftar di Bursa Efek Indonesia tahun 2013 sampai dengan tahun 2016 sejumlah 2.059 perusahaan. Sampel yang digunakan dalam penelitian ini berjumlah 300 perusahaan yang dipilih dengan menggunakan metode purposive sampling. Proses seleksi sampel berdasarkan kriteria yang telah ditetapkan tampak pada Tabel 4.1 berikut ini:

Tabel 4.1

Proses Seleksi Sampel

\begin{tabular}{|c|l|c|c|c|c|}
\hline No & \multicolumn{1}{|c|}{ Kriteria } & $\mathbf{2 0 1 3}$ & $\mathbf{2 0 1 4}$ & $\mathbf{2 0 1 5}$ & $\mathbf{2 0 1 6}$ \\
\hline 1. & Perusahaan yang terdaftar di BEI & 486 & 509 & 525 & 539 \\
\hline 2. & Perusahaan yang terdaftar di BEI sesudah tanggal 1 Januari & $(23)$ & $(23)$ & $(16)$ & $(14)$ \\
\hline 3. & Perusahaan yang melaporkan kerugian & $(129)$ & $(122)$ & $(130)$ & $(134)$ \\
\hline 4. & $\begin{array}{l}\text { Perusahaan yang tidak memiliki kelengkapan data laporan } \\
\text { keuangan yang sesuai variabel penelitian. }\end{array}$ & $(243)$ & $(256)$ & $(250)$ & $(262)$ \\
\hline 5. & $\begin{array}{l}\text { Perusahaan yang tidak menggunakan mata uang rupiah } \\
\text { Jumlah Sampel Perusahaan }\end{array}$ & $(36)$ & $(38)$ & $(42)$ & $(41)$ \\
\hline Jumlah Sampel Penelitian & & 70 & 87 & 88 \\
\hline
\end{tabular}

\section{Analisis Statistik Deskriptif}

Sumber : Data diolah, 2018 
Data yang diolah dalam penelitian ini dapat di deskripsikan seperti yang tersaji dalam

Tabel 4.2 berikut ini:

Tabel 4.2

Hasil Analisis Statistik Deskriptif

\begin{tabular}{|l|c|c|c|c|c|}
\hline \multicolumn{1}{|c|}{ Variabel } & $\mathrm{N}$ & Minimum & Maksimum & Mean & Std. Deviation \\
\hline Perencanaan Pajak & 300 & 0,07129 & 0,99400 & 0,7401535 & 0,16775011 \\
\hline Beban Pajak Tangguhan & 300 & 0,00001 & 0,12243 & 0,0036230 & 0,00966079 \\
\hline Aset Pajak Tangguhan & 300 & 0,00091 & 3,89852 & 0,3644327 & 0,46834999 \\
\hline Manajemen Laba & 300 & 0 & 1 & 0,57 & 0,496 \\
\hline
\end{tabular}

Sumber: Hasil SPSS yang diolah, 2018

Berdasarkan Tabel 4.2 menunjukkan bahwa perencanaan pajak yang diproksikan dengan Tax Retention Rate memiliki nilai rata-rata 0,7401535 dengan standar deviasi 0,16775011. Nilai minimum 0,07129 dan maksimum 0,99400. Nilai rata-rata yang lebih besar dari standar deviasi menunjukkan bahwa tidak terjadi perbedaan perencanaan pajak yang dilakukan oleh perusahaan yang terdaftar di Bursa Efek Indonesia.

Berdasarkan Tabel 4.2 menunjukkan bahwa aset pajak tangguhan yang diproksikan dengan Deffered Tax Asset memiliki nilai rata-rata 0,3644327 dengan standar deviasi 0,46834999. Nilai minimum 0,00091 dan maksimum 3,89852. Nilai rata-rata yang kurang dari standar deviasi menunjukkan bahwa terjadi perbedaan nilai aset pajak tangguhan yang dimiliki oleh perusahaan yang terdaftar di Bursa Efek Indonesia.

\section{Model Analisis Regresi Logistik}

\section{Menguji Kelayakan Model Regresi}

Kelayakan model regresi dinilai dengan menggunakan Hosmer and Lemeshow Goodness of Fit Test. Hosmer and Lemeshow Goodness of Fit Test menguji hipotesis nol bahwa data empiris cocok atau sesuai dengan model (tidak ada perbedaan antara model dengan data sehingga model dapat dikatakan fit).

Tabel 4.3

Hasil Pengujian Hosmer and Lemeshow Goodness of Fit Test

\begin{tabular}{|c|c|c|}
\hline Chi-Square & Df & Sig. \\
\hline 11,023 & 8 & 0,200 \\
\hline
\end{tabular}

Sumber: Hasil SPSS yang diolah, 2018

Berdasarkan Tabel 4.3 dapat diketahui bahwa nilai Chi-square adalah sebesar 11,023 dengan degree of freedom sebesar 8 dan nilai signifikansi sebesar 0,200 yang nilainya $>0,05$. Berdasarkan hasil tersebut keputusan yang diambil adalah hipotesis nol 
diterima yang berarti tidak ada perbedaan antara klasifikasi yang diprediksi dengan klasifikasi yang diamati. Hal tersebut menunjukkan bahwa model mampu memprediksi nilai observasinya atau model dapat diterima karena cocok dengan data observasinya sehingga model ini dapat digunakan untuk analisis selanjutnya.

\section{Menilai Keseluruhan Model (Overall Model Fit}

Tabel 4.4

\section{Hasil Uji Overall Model Fit}

\begin{tabular}{|l|l|}
\hline \multicolumn{1}{|c|}{ Block } & -2 Log Likelihood \\
\hline Block O (awal) & 409,989 \\
\hline Block 1 (akhir) & 398,897 \\
\hline
\end{tabular}

Sumber: Hasil SPSS yang diolah, 2018

Dari Tabel 4.4 menunjukkan bahwa angka -2Log Likelihood awal (block 0) adalah sebesar 409,989 sedangkan nilai -2Log Likelihood akhir (block 1) sebesar 398,897 yang artinya terjadi penurunan nilai -2Log Likelihood sebesar 11,092. Berdasarkan hasil tersebut menunjukkan bahwa model regresi baik dan penambahan variabel independen kedalam model mampu memperbaiki model fit.

Bukti Bahwa ada penurunan nilai -2Log Likelihood merupakan pengujian yang mengarah ke bentuk model yang fit dapat dilihat pada Tabel 4.4 berdasarkan nilai chisquare (nilai penurunan -2Log Likelihood) pada Omnibus Test of Model Coefficient berikut ini:

Tabel 4.5

Omnibus Tests of Model Coefficients

\begin{tabular}{|l|l|l|l|}
\hline & Chi-Square & Df & Sig. \\
\hline Perencanaan Pajak & 11,902 & 2 & 0,004 \\
\hline Aset Pajak Tangguhan & 11,902 & 2 & 0,004 \\
\hline
\end{tabular}

Sumber: Hasil SPSS yang diolah, 2018

Tabel 4.5 memperlihatkan nilai chi-square nilai selisih antara block 0 dan block 1 sebesar 11,902 dengan degree of freedom 2 dan dengan nilai signifikansi sebesar 0,004. Nilai signifikansi $0,004<0,05$. Hal ini berarti bahwa perencanaan pajak dan aset pajak tangguhan secara bersama-sama berpengaruh terhadap manajemen laba. 


\section{Koefisien Determinasi (Nagelkerke's R Square)}

Hasil dari pengujian koefisien determinasi ditunjukkan dalam Tabel 4.6 berikut ini:

Tabel 6

\section{Koefisien Determinasi}

\begin{tabular}{|c|c|}
\hline Persamaan & Nagelkerke $R$ Square \\
\hline Regresi Logistik & 0,049 \\
\hline
\end{tabular}

Sumber: Hasil SPSS yang diolah, 2018

Berdasarkan Tabel 4.6 dapat diketahui bahwa nilai Nagelkerke $R$ Square adalah sebesar 0,049 yang berarti variabilitas variabel dependen yang dapat dijelaskan oleh variabel independen (perencanaan pajak, beban pajak tangguhan dan aset pajak tangguhan) adalah sebesar 4,9\%, sedangkan sisanya sebesar 95,1\% dijelaskan oleh variabel-variabel lainnya diluar model penelitian.

\section{Tabel Klasifikasi}

Tabel 4.7

\section{Hasil Uji Ketepatan Klasifikasi Model}

\begin{tabular}{|c|c|c|c|c|}
\hline \multirow[b]{3}{*}{ Observasi } & & \multicolumn{3}{|c|}{ Prediksi } \\
\hline & & \multicolumn{2}{|c|}{ Manajemen Laba } & \multirow[b]{2}{*}{ Persentase Benar } \\
\hline & & $\begin{array}{l}\text { Small Loss } \\
\text { Firms }\end{array}$ & $\begin{array}{l}\text { Small Profit } \\
\text { Firms }\end{array}$ & \\
\hline \multirow[t]{2}{*}{ Manajemen Laba } & Small Loss Firms & 24 & 105 & 18,6 \\
\hline & Small Profit Firms & 11 & 160 & 93,6 \\
\hline \multicolumn{2}{|c|}{ Persentasi keseluruhan } & & & 61,3 \\
\hline
\end{tabular}

Sumber: Hasil SPSS yang diolah, 2018

Dari Tabel 4.7 dapat diketahui bahwa kekuatan prediksi dari model regresi untuk memprediksi kemungkinan perusahaan melakukan manajemen laba adalah sebesar 93,6\%. Hal ini menunjukkan bahwa dengan model regresi yang digunakan terdapat sebanyak 160 observasi $(93,6 \%)$ yang diprediksi melakukan manajemen laba dari total 171 observasi perusahaan yang diidentifikasikan melakukan manajemen laba. Kekuatan prediksi dari model regresi untuk memprediksi kemungkinan perusahaan tidak melakukan manajemen laba adalah sebesar 18,6\%. Hal ini berarti bahwa dengan model regresi yang digunakan sebanyak 24 observasi $(18,6 \%)$ yang diprediksi tidak melakukan manajemen laba dari total 129 observasi yang diidentifikasikan tidak melakukan manajemen laba. Secara keseluruhan ketepatan klasifikasi dalam penelitian ini adalah sebesar 61,3\%.

\section{Hasil Uji Regresi Logistik}

\section{Tabel 4.8}




\section{Hasil Uji Regresi Logistik}

\begin{tabular}{|l|c|c|c|}
\hline \multicolumn{1}{|c|}{ Hipotesis } & B & Sig & Keterangan \\
\hline Constans & $-1,443$ & 0,014 & \\
\hline $\begin{array}{l}\text { Perencanaan Pajak Berpengaruh Positif Terhadap } \\
\text { Manajemen Laba }\end{array}$ & 2,397 & 0,002 & Diterima \\
\hline $\begin{array}{l}\text { Aset Pajak Tangguhan Berpengaruh Terhadap Manajemen } \\
\text { Laba }\end{array}$ & $-0,132$ & 0,605 & Ditolak \\
\hline
\end{tabular}

Sumber: Hasil SPSS yang diolah, 2018

Berdasarkan Tabel 4.8 tersebut, persamaan regresi yang dibentuk adalah sebagai berikut:

$$
\operatorname{Ln} \frac{E M}{1-E M}=-1,443+2,397 T R R-0,132 D T A+e
$$

Dari persamaan regresi tersebut maka dapat diketahui:

\section{1) Pengujian Hipotesis Pertama}

Variabel perencanaan pajak diukur dengan tax retention rate (TRR) memiliki nilai koefisien regresi positif sebesar 2,397 dan probabilitas (sig) sebesar 0,002. Nilai probabilitas (sig) lebih kurang dari $\alpha(0,002<0,05)$, sehingga perencanaan berpengaruh signifikan terhadap manajemen laba. Dengan demikian hipotesis pertama (H1) diterima.

2) Pengujian Hipotesis Kedua

Variabel aset pajak tangguhan diukur dengan defferred tax asset (DTA) memiliki nilai koefisien regresi negatif sebesar $-0,132$ dan probabilitas (sig) sebesar 0,605. Nilai probabilitas (sig) lebih besar dari $\alpha(0,672>0,05)$, sehingga aset pajak tangguhan tidak berpengaruh signifikan terhadap manajemen laba. Dengan demikian hipotesis ketiga $(\mathrm{H} 2)$ ditolak.

\section{Pembahasan}

\section{Pengaruh Perencanaan Pajak terhadap Manajemen Laba}

Berdasarkan hasil pengujian hipotesis pertama (H1) diperoleh nilai koefisien regresi sebesar 2,275 dan signifikansi sebesar 0,002 <0,05 yang menunjukkan bahwa perencanaan pajak berpengaruh positif signifikan terhadap manajemen laba. Hal ini berarti perencanaan pajak yang dilakukan mempengaruhi perusahaan dalam melakukan manajemen laba, dengan adanya perencanaan pajak maka perusahaan dapat memperkecil pembayaran pajak. Hal ini disebabkan karena perusahaan go publik cenderung tidak ingin membayar pajak 
yang tinggi sesuai dengan laba yang diperoleh perusahaan sehingga perusahaan melakukan manajemen laba melalui perencanaan pajak.

Hasil pengujian ini tidak sejalan dengan penelitian yang dilakukan oleh Aditama dan Purwaningsih (2014), Singkianti (2015), Sari (2016), dan Endriati dkk (2017) yang menyatakan bahwa perencanaan pajak tidak berpengaruh terhadap manajemen laba. Namun, hasil penelitian ini sejalan dengan penelitian yang dilakukan oleh Fitriyany (2016), Santana dan Wirakusuma (2016) dan Negara dan Suputra (2017) yang menyatakan bahwa perencanaan pajak berpengaruh positif terhadap manajemen laba.

\section{Pengaruh Aset Pajak Tangguhan terhadap Manajemen Laba}

Berdasarkan hasil pengujian hipotesis ketiga (H3) diperoleh diperoleh nilai koefisien regresi sebesar $-0,110$ dan nilai signifikansi sebesar 0,672>0,05 yang menunjukkan bahwa aset pajak tangguhan tidak berpengaruh signifikan terhadap manajemen laba. Hal ini berarti besarnya aset pajak tangguhan perusahaan tidak mempengaruhi perusahaan dalam melakukan manajemen laba untuk menghindari penurunan laba. Tidak berpengaruhnya aset pajak tangguhan terhadap manajemen laba karena apabila aset pajak tangguhan perusahaan mempercepat suatu pengakuan pendapatan atau menangguhkan beban, maka akan menyebabkan beban pajak yang harus di bayar di masa yang akan datang akan menjadi lebih besar yang justru bisa merugikan perusahaan.

Hasil penelitian ini tidak sejalan dengan penelitian yang dilakukan oleh Fitriyany (2016) dan Hakim dan Praptoyo (2015) yang menyatakan bahwa aset pajak tangguhan berpengaruh positif signifikan terhadap manajemen laba. Namun penelitian ini sejalan dengan penelitian yang dilakukan oleh Singkianti (2015), Mettawidya (2015), dan Sari (2016) yang menyatakan bahwa aset pajak tangguhan tidak berpengaruh signifikan terhadap manajemen laba.

\section{KESIMPULAN}

Berdasarkan hasil analisis tentang pengaruh perencanaan pajak, beban pajak tangguhan dan aset pajak tangguhan terhadap manajemen laba, maka dapat diperoleh kesimpulan sebagai berikut:

Perencanaan pajak berpengaruh positif signifikan terhadap manajemen laba. Hasil penelitian ini sejalan dengan penelitian yang dilakukan oleh Fitriyany (2016), Santana dan Wirakusuma (2016) dan Negara dan Suputra (2017) yang menyatakan bahwa perencanaan 
pajak berpengaruh positif terhadap manajemen laba sedangkan aset pajak tangguhan tidak berpengaruh signifikan terhadap manajemen laba. Hasil penelitian ini sejalan dengan penelitian yang dilakukan oleh Singkianti (2015), Mettawidya (2015), dan Sari (2016).

\section{Keterbatasan}

Variabel bebas yang diuji hanya meliputi perencanaan pajak, beban pajak tangguhan dan aset pajak tangguhan yang hanya mampu mempengaruhi 5\% manajemen laba sehingga masih memungkinkan adanya pengaruh variabel bebas lainnya diluar ketiga variabel tersebut.

Metode pengukuran manajemen laba yang digunakan dalam penelitian ini menggunakan metode pendekatan distribusi laba, dimana model ini bukan model yang paling ajurat untuk mendeteksi manajemen laba. Menurut Yulianti (2005) model distribusi laba tidak dapat memisahkan perusahaan dalam area small profit firms yang melakukan manajemen laba dan tidak melakukan manajemen laba, sehingga model distribusi laba ini menganggap semua perusahaan yang berada pada area tersebut sebagai pengukur manajemen laba.

\section{Saran}

Peneliti selanjutnya diharapkan dapat menambahkan variabel bebas baru yang dapat mempengaruhi manajemen laba. Seperti liabilitas pajak tangguhan, karena menurut Astana (2015) liabilitas pajak tangguhan dapat digunakan untuk meningkatkan jumlah laba tahun berjalan dalam perusahaan. Selain itu variabel bebas lainnya yang disarankan adalah beban pajak kini, karena menurut Widiariani dan Sukartha (2015) beban pajak kini mencerminkan pajak penghasilan yang merupakan hasil rekonsiliasi beda tetap dan beda waktu terhadap laba akuntansi, sehingga beban pajak kini yang diperbesar maupun diperkecil dapat mempengaruhi besar kecilnya laba perusahaan.

Peneliti selanjutnya diharapkan dapat menggunakan model lain untuk memprediksi manajemen laba, yaitu model pendekatan baru yang diciptakan oleh Dechow dkk (2011), sebagaimana yang diungkapkan oleh Suyono (2017) bahwa metode Dechow dkk merupakan metode yang paling akurat untuk memprediksi manajemen laba.

\section{DAFTAR PUSTAKA}

Aditama, Ferry dan Anna Purwaningsih. 2014. Pengaruh Perencanaan Pajak Terhadap Non Manajemen Laba pada Perusahaan Manufaktur yang Terdaftar di Bursa Efek Indonesia. Modus Vol. 26. ISSN: 0852-1875. Universitas Atma Jaya Yogyakarta.

Chariri, Anis. Imam Gozhali. 2003. Teori Akuntansi Internastional Financial Reporting System (IFRS) edisi empat. Badan Penerbit Universitas Diponegoro. 
Endriati, Enny, Hj. Nur Hidayati dan Junaidi . 2017. Pengaruh Perencanaan Pajak terhadap Manajemen Laba Pada Perusahaan Non Manufaktur yang Terdaftar di Bursa Efek Indonesia. Universitas Negeri Malang.

Ghozali, Imam. 2016. Aplikasi Analisis Multivariete dengan Program IBM SPSS 23 Edisi 8. Penerbit : Badan Penerbit Universitas Diponegoro.

Hakim, Arif Rachmad dan Sugeng Praptoyo. 2015. Pengaruh Aktiva Pajak Tangguhan dan Beban Pajak Tangguhan terhadap Manajemen Laba. Jurnal Ilmu dan Riset Akuntansi Vol. 2 No. 7. Sekolah Tinggi Ilmu Ekonomi Indonesia : Surabaya.

Hery. 2012. Analisis Laporan Keuangan. Jakarta: Bumi Aksara.

Jensen, Michael C and Hilliam H. Meckling. 1976. Theory of the Firm : Managerial Behavior Agency Cost And Ownership Structure. Journal of Finansial Economics. October V.3 No.4 PP. 305-306.

Mettawidya, Stella. 2015. Analisis Pengaruh Aset Pajak Tangguhan, Asimetra Informasi dan Ukuran Perusahaan terhadap Manajemen Laba pada Perusahaan LQ45 yang Terdaftar di Bursa Efek Indonesia tahun 2010-2012. Jom Fekon Vol. 2 No.1. Pekanbaru : Universitas Riau.

Nazir, Moh. 2005. Metode Penelitian. Jakarta : Ghalia Indonesia.

Negara, A.A Gede Raka Plasa dan I.D.G Dharma Suputra. 2017. Pengaruh Perencanaan Pajak, Beban Pajak Tangguhan dan Aset Pajak Tangguhan terhadap Manajemen Laba. E-Jurnal Akuntansi Universitas Udayana Vol.20.3 September (2017):20452072. Bali: Universitas Udayana.

Pindiharti, Dewi. 2011. Pengaruh Aktiva Pajak Tangguhan, Beban Pajak Tangguhan dan Akrual Terhadap Earning Management (Studi Empiris pada Perusahaan Manufaktur di Bursa Efek Indonesia). Skripsi. Universitas Islam Negeri Syarif Hidayatullah Jakarta.

Phillips, John, Morton Pincus dan Sonja Olhoft Rego. 2002. Earnings Management : New Evidence Based on Deffered Tax Expense. The Accounting Review. No. 77 pp 291-521.

PSAK No. 46 Pajak Penghasilan. 2010. Exposure Draft Pernyataan Standar Akuntansi Keuangan. Ikatan Akuntan Indonesia.

Purba, Margaretha Angela. 2016. Pengaruh Aset Pajak Tangguhan dan Beban Pajak Tangguhan terhadap Manajemen Laba pada Perusahaan Manufaktur yang Terdaftar di Bursa Efek Indonesia Tahun 2011-2014. Skripsi. Universitas Sumatera Utara.

Santana, Dewa Ketut Wira dan Made Gede Wirakusuma. 2016. Pengaruh Perencanaan Pajak, Kepemilikan Manajerial dan Ukuran Perusahaan terhadap Praktik Manajemen Laba. E-Jurnal Akuntansi Universitas Udayana.14.3.

Schipper, Katherine (1989). Comentary Khaterine on Earnings Management . Accounting Horizon.

Scoot, William R. 2000. Financial Accounting Theory 6th Edition. Prentice Hall Canada Inc.

Suandy, Erly. 2011. Perencanaan Pajak Edisi 5. Jakarta: Penerbit Salemba Empat.

Sulistyanto, H. Sri. 2008. Manajemen Laba, Teori dan Model Empiris. Jakarta : Grasindo.

Sulistiawan, Dedhi, Yeny Januarsi dan Liza Alvia. 2011. Creative Accounting : Mengungkap Manajemen Laba dan Skandal Akuntansi. Jakarta : Salemba Empat. 
Tundjung, Ghafara Mawaridi Mazini. 2015. Pengaruh Beban Pajak Tangguhan terhadap Manajemen Laba (Studi Empiris Pada Perusahaan Manufaktur yang Terdaftar di Bursa Efek Indonesia. Skripsi. Universitas Diponegoro Semarang.

Wild, John J., K. R. Subramanyam and Robert F. Halsey. 2005. Financial Statement Analysis (Analisis Laporan Keuangan) Edisi 8 Buku Satu. Penerbit : Salemba Empat. 